HUOM! Tämä on alkuperäisen artikkelin rinnakkaistallenne. Rinnakkaistallenne saattaa erota alkuperäisestä sivutukseltaan ja painoasultaan.

Käytä viittauksessa alkuperäistä lähdettä:

Rakhshanda, K. \& Melkas, H. (2020) The social dimension of frugal innovation. International Journal of Technology Management, 83(1), 160-179. DOI: 10.1504/IJTM.2020.109234

PLEASE NOTE! This in an electronic self-archived version of the original article. This reprint may differ from the original in pagination and typographic detail.

Please cite the original version:

Rakhshanda, K. \& Melkas, H. (2020) The social dimension of frugal innovation. International Journal of Technology Management, vol 83(1), 160-179. DOI: 10.1504/IJTM.2020.109234

The final version of the article is available online at http://dx.doi.org/10.1504/IJTM.2020.109234 (C) 2020 Inderscience publishers. 


\title{
The social dimension of frugal innovation
}

\section{Rakhshanda Khan*}

\author{
Business Programmes Unit, \\ Haaga-Helia University of Applied Sciences, \\ Ratapihantie 13, 00520 Helsinki, Finland \\ Email: rakhshanda.khan@haaga-helia.fi \\ *Corresponding author
}

\section{Helinä Melkas}

\author{
School of Engineering Science, \\ LUT University, \\ Lahti Campus, \\ Mukkulankatu 19, 15210 Lahti, Finland \\ Email: helina.melkas@lut.fi
}

\begin{abstract}
In the layperson's mind, the term frugal innovation evokes ideas of frugality and cheap solutions. Experts share a broader understanding of frugal innovation as the ability to do more with less by increasing business and social value (Radjou and Prabhu, 2014). Emerging researches focus on its strategic, technological and organisational aspects. However, the core of frugal innovation is its social dimension, yet this has generally been overlooked. The aim of this paper is to explore the social dimension by showing the potential of frugal innovation to prompt social innovation. Empirical material derived from four case studies of frugal innovation illustrates this strong social dimension. Frugal innovation adds value by producing solutions cheaper than the alternatives, and allows non-consumers to become consumers, which itself is social innovation. This paper presents a novel view of frugal innovation and social innovation as closely related. The umbrella term socially driven innovation is suggested to incorporate both social and frugal innovation.
\end{abstract}

Keywords: frugal innovation; social innovation; socially driven innovation; frugality.

Reference to this paper should be made as follows: Khan, R. and Melkas, $\mathrm{H}$. (2020) 'The social dimension of frugal innovation', Int. J. Technology Management, Vol. 83, Nos. 1/2/3, pp.160-179.

Biographical notes: Rakhshanda Khan works as a Senior Lecturer in International Business at the Haaga-Helia University of Applied Sciences. She has worked as a Postdoctoral Researcher in the Department of Business and Management in Innovation Systems at the Lappeenranta University of Technology (LUT), Finland. She holds a PhD in Business and Management from the LUT. Her expertise lies in sustainable socially driven businesses and inclusive business models, with a special focus on frugal innovation. She has published in several refereed journals like Applied Energy, Sustainability, Journal of Innovation and Sustainable Development, International Journal of Information and Social Change among others. She has received a number of awards for her academic achievements. 
Helinä Melkas is a Professor of Industrial Engineering and Management (especially service innovations) at the Lappeenranta-Lahti University of Technology LUT, Finland. She has worked at the LUT, Lahti Campus since 2007. In recent years, she has conducted research on inter alia, innovation management at policy and organisational levels, regional development, practice-based innovation processes, social enterprises and public services. She has published numerous articles in international and national scientific journals and books.

\section{Introduction}

Frugal innovation has become an increasingly significant topic in recent years (EU - European Commission, 2016). In the layperson's mind, it evokes ideas of frugality, cheap solutions and products designed under resource constraints (Bessant, 2016). Experts in this field, though, share a broader understanding of frugal innovation as the "ability to do more with less by creating more business and social value while minimising the use of resources such as energy, capital and time" (Radjou and Prabhu, 2014). So far, the discussion on frugal innovation has dealt with numerous strategic, technological and organisational topics. Current frameworks of frugal innovation help in understanding its attributes and significance, while other studies propose a theoretical understanding contrasting frugal innovation to other forms of innovation, such as good-enough, constraint-based and reverse innovation (Zeschky et al., 2014).

Most authors agree that frugal innovation refers to affordable products and services that meet the needs of consumers with modest lifestyles (Basu et al., 2013; Zeschky et al., 2011). Frugal innovation provides social value by producing solutions cheaper than alternatives. However, social value, although recognised as relevant to frugal innovation, is largely overlooked. The social dimension is the core of frugal innovation, yet there is an absence of discussion on it. For example, what happens when the needs of consumers with modest lifestyles are met? What does this process of making non-consumers into consumers signify? What happens when those on the margins of society are included in the mainstream or when companies innovate for the bottom of the pyramid? These questions remain unanswered, and the societal significance of frugal innovation is rarely discussed.

Despite increasing research on frugal innovation in recent years, academic studies on many important aspects are still lacking. The present study differs from previous work by focussing on the significant but unexplored social dimension of frugal innovation. To fill this gap, the authors examine the blurring boundaries between frugal innovation and social innovation to highlight the social dimension of frugal innovation. The authors seek to present a view on frugal innovation and social innovation as closely related within the umbrella term socially driven innovation, which is seen as solutions and processes that generate social value and result in social health and well-being (Khan, 2017).

The remainder of this paper is structured as follows. The next section provides an overview of two essential concepts - frugal innovation and social innovation - and then explains the methodological approach. The results section discusses the four well-known cases of frugal innovation and analyses them from the social innovation perspective. Next, the discussion section considers the blurred lines between frugal innovation and 
social innovation and proposes the concept of socially driven innovation. Finally, the authors point out the theoretical and managerial implications of this research, discuss its limitations and give recommendations for future research. For the purposes of this paper, the authors adopt Weyrauch and Herstatt's (2017) three defining criteria of frugal innovation. According to Weyrauch and Herstatt (2017), "innovations are frugal if they simultaneously meet the criteria substantial cost reduction, concentration on core functionalities, and optimised performance level."

\section{Theoretical framework}

\subsection{Frugal innovation}

Academic research on frugal innovation is evolving, and business professionals and researchers have started to realise the importance of a frugal mindset and its implications for firms in both emerging and developed markets (Pisoni et al., 2018). The varied origins of the literature on frugal innovation have led to diverse interpretations. Frugal innovation is closely related to concepts such as reverse innovation (Govindarajan and Ramamurti, 2011), jugaad innovation (Radjou et al., 2012), bottom-of-pyramid innovation (Prahalad and Hart, 2002) and grassroots innovation (Smith et al., 2014). Presented and defined differently, these concepts share similar principles as frugal innovation; for instance, simplicity, affordability and accessibility.

Over the years, many definitions of frugal innovation have been proposed and classified as product- and process-oriented (EU - European Commission, 2016). On one hand, the product-oriented definitions capture the characteristics or product-based features of a frugal solution. Tiwari and Herstatt (2012b, p.4), for instance, define it as an innovation that "seeks to minimise the use of material and financial resources in the complete value chain with the objective of reducing the cost of ownership while fulfilling or even exceeding certain predefined criteria of acceptable quality standards." Rao (2013, p.69) notes that "frugal innovation is characterised by low price, compact design, use of limited raw materials or reuse of existing components, ease of use and use of cutting-edge technology to achieve lower costs." On the other hand, the process-oriented definitions capture the design and delivery contexts. For instance, Basu et al. (2013, p.64) refer to frugal innovation as a "design innovation process in which the needs and context of citizens in the developing world are put first in order to develop appropriate, adaptable, affordable, and accessible services and products for emerging markets." Radjou and Prabhu (2014) define frugal innovation as the means and ends to do more with less for more people.

There has been an increasing academic interest in how frugal innovation acts as a promising product category for western corporations or how they are organising frugal innovation efforts and adapting to principles of frugal innovation in order to successfully expand to the unexploited emerging markets (Zeschky et al., 2011). Scholars have been investigating how multinational corporations (MNCs) can effectively tap into the bottom of pyramid markets and catch up with their local competitors (Prahalad, 2010). Nevertheless, others have also been interested in exploring frugal innovation, which is undertaken by grassroots innovators, who have the potential to deliver affordable products and services, empower local communities and promote more inclusive 
patterns of development (Fressoli et al., 2014; Papaioannou, 2014). The focus of such research has been on the study of processes (i.e., how innovation emerges from resource-constrained settings). As a result, low-cost, effective and resource-efficient solutions are produced, which are impossible to realise under conditions of resource affluence (Pansera and Sarkar, 2016).

The concept of frugal innovation, introduced to meet the needs of low-income markets (Hart and Christensen, 2002; Prahalad, 2010), has become seen as also necessary in developed markets (Bound and Thornton, 2012; Radjou and Prabhu, 2015). Across developed markets, the applicability of frugal innovation to advanced economies has been studied (EU - European Commission, 2016), and its low costs and no-frills structure have gained popularity (Rao, 2013) as poor customers in developed markets also need to be served. Scholars and practitioners, therefore, are both interested in understanding how the frugal mindset can be incorporated into firms' business models (Angot and Ple, 2015). Frugal innovation generates good-enough, affordable products that meet the needs of resource-constrained consumers [Zeschky et al., (2011), p.38]. Although terms such as low cost, affordable and resource constraints are typically associated with frugal innovation, it is also about more. Neither is it solely about redesigning products; it involves rethinking entire production processes and business models. Frugal innovation is more of a mindset than a particular type of innovation (Soni and Krishnan, 2014).

A recent study by Pisoni et al. (2018) points towards important future directions for research on frugal innovation, including fostering collaboration among the actors involved in frugal innovation processes and learning from community engagement issues that demand serious attention. Bhatti (2012) proposes a framework positioning frugal innovation at the intersection of technology innovation, institutional innovation and social innovation. Frugal innovation can create social value (Basu et al., 2013; Radjou and Prabhu, 2014) by boosting the standard of living in individual communities to the next-better level (Tiwari and Herstatt, 2012b). Frugal innovation focusses on meeting the needs of citizens and designing solutions suitable for them (Basu et al., 2013).

The western world is adopting frugal innovation amid growing disparities between the rich and the middle class and a disconnect between existing products and services and the basic needs of customers (Bound and Thornton, 2012). However, these are not the only reasons for this shift. Consumers' perspectives have also shifted as the developed world has become conscious of costs and sustainability. Frugal innovation and sustainability increasingly are closely identified. Consumer frugality is driven not only by resource constraints but also by changing values, such as a focus on durability and environmental sustainability and a desire for lower consumption (EU - European Commission, 2016).

\subsection{Social innovation}

A debate on what social innovation is and how it should be defined (Chiappero-Martinetti et al., 2017) has raged for several years (e.g., BEPA, 2010). The concept of social innovation has its roots in the social sciences in the 1960s but was not systematically utilised until the 1990s. Although the concept is widely used, its contents have remained undefined and abstract. Both words - social and innovation - refer to ambiguous concepts that allow for many interpretations (Joutsenoja and Lindh, 2004). Some definitions of social innovation are specific and exclude practical examples, especially 
those from the private sector. Other definitions are very broad including examples that are not particularly innovative (Hennala, 2011).

Chiappero-Martinetti et al. (2017) note that no generally agreed-upon definition of social innovation has emerged; instead, there is a range of uses and considerable fluidity and diversity in meanings and interpretations within research and practice. Nicholls and Ziegler (2015) define social innovation as "the development and delivery of new ideas and solutions (products, services, models, modes of provision, processes) at different socio-structural levels that intentionally seek to change power relations and improve human capabilities, as well as the processes via which these solutions are carried out." In a bibliometric analysis of the 'coming to be' of social innovation, Ayob et al. (2016) identify two contesting streams of research: the first on outcomes and social value production and the second on changes in power relations and new social processes and relations aimed at rebalancing power disparities and economic inequalities. Recently, however, the disagreement seems to have lessened as both the outcome and the process are increasingly emphasised by scholars (Chiappero-Martinetti et al., 2017). For instance, Moulaert et al. (2013) stress both changes in power relations and improved human capabilities.

According to Joutsenoja and Lindh (2004), social innovation can be any individual and social development or social, economic and cultural action regardless of time and place. The broadest definitions describe social innovation as the public good benefiting people or the planet (Centre for Social Innovation, 2013), improving the macro-level quality of life or increasing life expectancy (Pol and Ville, 2009). Changes in ways of thinking can also be referred to as social innovation; adaptations of mental models and institutional and social norms that increase society's ability to renew itself, novel solutions to social problems with societal value (e.g., Phills et al., 2008; Ståhle et al., 2004) and new ideas that aid achieving social goals (Mulgan et al., 2007). Moreover, it can be a question of changes in the cultural, normative or regulative structure of a society that increase the collective power of its resources and improve its economic and social performance (Heiskala, 2007; Hennala, 2011).

However, there is a risk that the concept's fluidity and malleability conceal value differences and conflicts of interest (Chiappero-Martinetti et al., 2017). To overcome this danger, Chiappero-Martinetti et al. (2017) propose the capability approach that includes an analysis of entangled facts and values (Putnam, 2002) and sheds light on the evaluative dimension of social innovations, their presuppositions and policy consequences, intervention design and attempts at scaling up (Ziegler, 2015). Chiappero-Martinetti et al. (2017) claim that the recent increased interest in social innovation may be partly due to the collapse in trust in the status quo since the 2008-2009 global financial crisis. The capability approach can play a role in research and practice when established approaches fail, and there is a need to create space for the discussion of alternatives (Chiappero-Martinetti et al., 2017).

Social innovation often refers to the invention, diffusion and adoption of new services and organisational models in the non-profit, public and private sectors, among which innovations often move between as they evolve. The BEPA (2010) report gives the following definition: "social innovations are innovations that are social both in their ends and in their means. Specifically, this study defines social innovations as new ideas (products, services and models) that simultaneously meet social needs (more effectively than alternatives) and create new social relationships or collaborations. In other words, 
they are innovations that are both good for society and enhance society's capacity to act." This definition is still rather broad but offers some guidance for distinguishing between social innovation and other, similar innovation types.

Social innovation is also linked to novel ways to doing things and to seeing old and new challenges and, more generally, to the ability to see behind and beyond the usual. Thus, social innovation needs not be large and significant but can be generated and formed from many different starting points. Social innovation gives communities opportunities to assess and develop their own operations and take into account users' views (Hämäläinen, 2005). It needs to be noted, however, that considering service users is not by itself sufficient action to guarantee that social innovation is user-driven. Despite the increasingly holistic view on innovation, social innovation is often accorded secondary importance. Support and management of social innovation require an approach that is sufficiently nuanced. Any innovation entails the risk that it might address social or economic needs inappropriately or fail to do so at all (Osborne and Brown, 2011). A nuanced approach needs to go beyond simple innovation 'recipes' and look into the configurations, contingencies and complexities that are required for social innovation. The appropriateness of social innovation is essential. Innovation may be the wrong response to expressed needs and even risk the loss of vital existing expertise and competencies (Osborne and Brown, 2011; cf. Van de Ven, 1988). The implementation of truly empowering, bottom-up, inclusive approaches to innovation (e.g., Hennala et al., 2011, 2012) can contribute to avoiding these risks. Long-term impacts on people, society, the economy, the environment of the innovation process and the resulting innovations should be taken into account (Hautamäki, 2007).

Moulaert et al. (2013, p.2) note that "socially innovative actions, strategies, practices and processes arise whenever problems of poverty, exclusion, segregation and deprivation or opportunities for improving living conditions cannot find satisfactory solutions in the 'institutionalised field' of public or private action." EU policy documents, for instance, are based on the presumptive belief in the transformative potential of social innovation. The major question then is how the goal of bottom-up, emancipatory processes can be advanced in society. Chiappero-Martinetti et al. (2017) argue that the key is to include marginalised groups in policy design and implementation, incorporating the doings and beings they value from the outset. Tiwari (2017) also highlights people's aspirations as crucially important: space for the articulation of individual and group aspirations creates space for social innovations.

\section{Methods}

This study is based on a literature review of the Web of Science and Scopus database conducted in 2016, which selected 73 publications from the frugal innovation literature. The aim was to review a representative sample of papers from the frugal innovation literature to gain a sufficient understanding of the topic and understand its connection to social sustainability. The frugal innovation characteristics and its societal implications were identified from the literature. Most materials studied individual examples, so the characteristics of frugal innovation were derived from the work of the selected authors (Khan, 2016). 
Table 1

Criteria for frugal innovation

\begin{tabular}{|c|c|c|c|}
\hline \multirow{2}{*}{ Innovation } & \\
\hline & $\begin{array}{l}\text { Substantial cost } \\
\text { reduction }\end{array}$ & $\begin{array}{l}\text { Concentration on core } \\
\text { functionalities }\end{array}$ & $\begin{array}{c}\text { Optimised performance } \\
\text { level }\end{array}$ \\
\hline $\begin{array}{l}\text { Narayana } \\
\text { Hrudayalaya } \\
(\mathrm{NH})\end{array}$ & $\begin{array}{l}\text { Heart surgery costs at } \\
\text { NH range from } \\
\text { US } \$ 2,000-\$ 5,000 \text {, } \\
\text { significantly lower than } \\
\text { US } \$ 20,000-\$ 100,000 \\
\text { in the USA. }\end{array}$ & $\begin{array}{l}\text { Focus on essential } \\
\text { functions. } \\
\text { - High volume of } \\
\text { surgeries: NH } \\
\text { surgeons perform } \\
1-5 \text { operations per } \\
\text { day, thereby reducing } \\
\text { the per-unit cost of } \\
\text { surgery. } \\
\text { - Asset light strategy: } \\
\text { minimises inventory } \\
\text { costs; partners with } \\
\text { other hospitals to } \\
\text { share fixed costs. } \\
\text { - Leases equipment and } \\
\text { reduces building costs } \\
\text { in order to reduce } \\
\text { expenses. }\end{array}$ & $\begin{array}{l}\text { Performance level fits the } \\
\text { intended purpose and local } \\
\text { conditions. } \\
\text { - Provides first-class } \\
\text { cardiac care through } \\
\text { mass production and } \\
\text { lean manufacturing. } \\
\text { - Provides free or cheap } \\
\text { surgeries to } 13 \% \text { of all } \\
\text { patients through income } \\
\text { from clients who pay. }\end{array}$ \\
\hline
\end{tabular}

General electric's MAC 400 was

MAC 400

electrocardiogram

(ECG) machine

\section{Siemens \\ CT scanner (SOMATOM Spirit)}

launched in India for US\$1,000 in 2008.

Costs one-tenth of its equivalent in western markets and reduces the cost of an ECG to just US\$1 per patient.

\section{Focus on essential} functions that fit local conditions.

- Compact size, battery-powered and easy to carry on bikes while visiting patients in far- flung villages.

- Uses rugged printer.

- Very easy to operate by non-specialists.

Reduces treatment costs by $30 \%$. This scanner costs around US $\$ 60,000$, which is significantly lower than the different types of CT scanners ranged between US $\$ 1,000,000$ and $\$ 2,500,000$.

Focus on essential conditions.

- Designed for diagnosing sports-related injuries and other common ailments.
Performance level fits the intended purpose and local conditions.

- Performance fits the requirements of doctors as well as patients in rural areas. Doctors need simple, portable ECG devices that can be carried to villages.

- Performance fits the requirement of quick diagnosis of heart conditions. Performance level fits the functions that fit local intended purpose and local conditions.

- Very easy to use by less qualified healthcare workers, such as technicians.
- Performance fits the requirements of users as they need simple solutions, such as basic diagnosing.

- Scans more patients daily and consumes less energy and reduces radiation dosage by up to $60 \%$. 
Table 1 Frugal innovation cases and criteria (continued)

\begin{tabular}{|c|c|c|c|}
\hline \multirow[b]{2}{*}{ Innovation } & \multicolumn{3}{|c|}{ Criteria for frugal innovation } \\
\hline & $\begin{array}{l}\text { Substantial cost } \\
\text { reduction }\end{array}$ & $\begin{array}{l}\text { Concentration on core } \\
\text { functionalities }\end{array}$ & $\begin{array}{c}\text { Optimised performance } \\
\text { level }\end{array}$ \\
\hline $\begin{array}{l}\text { Vortex } \\
\text { Engineering } \\
\text { (solar powered } \\
\text { ATM) }\end{array}$ & $\begin{array}{l}\text { Vortex machines } \\
\text { cost } 50 \% \text { less than } \\
\text { conventional ATMs. }\end{array}$ & $\begin{array}{l}\text { Focus on essential } \\
\text { functions that fit local } \\
\text { conditions. } \\
\text { - Designed to operate } \\
\text { without air } \\
\text { conditioning. } \\
\text { - Very easy to use } \\
\text { fingerprint-based } \\
\text { biometric } \\
\text { authentication system } \\
\text { that works well for } \\
\text { illiterate people. } \\
\text { - Sheet separation } \\
\text { apparatus technology } \\
\text { to dispense even } \\
\text { soiled notes. } \\
\text { - Operates under power } \\
\text { fluctuations and } \\
\text { power failures - has } \\
\text { built-in battery } \\
\text { back-up for up to } \\
4 \text { hours. }\end{array}$ & $\begin{array}{l}\text { Performance level fits the } \\
\text { intended purpose and local } \\
\text { conditions. } \\
\text { - Performance fits } \\
\text { requirements of users in } \\
\text { rural areas, as they need } \\
\text { simple, rugged and easy } \\
\text { to use ATMs. } \\
\text { - Solar-powered, } \\
\text { environmentally-friendly } \\
\text { ATM consumes } 10 \% \\
\text { of the total energy } \\
\text { requirement of a regular } \\
\text { ATM. } \\
\text { - Generates less heat. }\end{array}$ \\
\hline
\end{tabular}

This study extends the review to the social innovation literature and employs a case study approach to understand the social dimension of frugal innovation. This approach suits this study as the social dimension of frugal innovation is a relatively new research area, and limited knowledge on it is available (Yin, 2009). To select the four cases for this study, the authors applied purposive sampling to understand the phenomenon at hand (Onwuegbuzie and Leech, 2007) and to fulfil the study purpose to gain deeper insights into the social dimension of frugal innovation. The authors selected these cases (Table 1) based on the following criteria. First, they qualify the three defining criteria of frugal innovation (Weyrauch and Herstatt, 2017). Table 1 illustrates how these innovations fulfil the three defining criteria of frugal innovation. Second, all four are prominent cases attracting significant media attention. Finally, they capture the inherent social dimension and have positive impacts on society. This study explores the social dimension of frugal innovation through these four cases, utilising the characteristics of social innovation identified in the literature. The authors derived the social innovation characteristics through social innovation definitions and extracted the important characteristics from each definition. During the analysis, the authors discovered that many characteristics could be grouped under the same category. For example, 'individual and social development', 'public good', 'improving quality of life', 'human well-being' and 'improve the performance of society' were many characteristics that could be grouped together as 'improves human capabilities and promotes well-being'. Moreover, in order to limit the number of characteristics, the authors combined complementary characteristics. Finally, the authors derived five main characteristics of social innovation, 
which include 'sustainable solution', 'novel solution beneficial for society', 'socially inclusive and rebalances power disparities', 'overcomes societal challenges' and 'improves human capabilities and promotes well-being'. Each case of frugal innovation was evaluated according to these five characteristics of social innovation.

Table 1 illustrates how Narayana Hrudayalaya (NH), general electric's (GE's) MAC 400 ECG machine, Siemens CT scanner (SOMATOM Spirit) and Vortex Engineering (solar powered ATM) fulfil the three defining criteria for frugal innovation (Weyrauch and Herstatt, 2017).

\section{Results and analysis}

\subsection{Narayana Hrudayalaya}

\subsubsection{Case description}

NH is a hospital chain in India founded in 2000 by Devi Shetty, an Indian cardiac surgeon, with the vision to provide "high-quality healthcare, with care and compassion, at an affordable cost, on a large scale" [Davidson, (2015), p.7]. NH delivers affordable, quality tertiary care, including cardiac services, neurosciences, oncology and organ transplants. NH provides world-class yet cost-effective cardiac care by applying the principles of lean manufacturing and mass production. Heart surgery costs range from US\$2,000-\$5,000, significantly lower than US\$20,000-\$100,000 in the USA. Low-income patients receive operations free of charge. $\mathrm{NH}$ conducts at least 60 operations for poor patients weekly but is able to achieve a higher profit margin than the standard US healthcare centre (Bound and Thornton, 2012). NH has become a well-known example of frugal innovation globally. According to Shetty, "we didn't intend to become a frugal innovation. We just didn't have the money, so we looked at breakthrough innovations, like the mobile phone and the automobile, and how they gained traction" [Davidson, (2015), p.10].

\subsubsection{Analysis of NH from the social innovation perspective}

According to Pol and Ville (2009), social innovation improves the macro quality of life or that related to a group. Given this definition, it is highly probable that NH presents a case not only of frugal innovation as the authors recognise it but also of social innovation. NH promotes well-being by offering cost-effective cardiac care and implementing an innovative healthcare model. Furthermore, it enables access to healthcare for people with low incomes. NH offers a micro-insurance scheme through which the poor can access quality healthcare at five Indian rupees per month. Only $8 \%$ of the world's population can afford heart surgery, and in India, there is need for two million heart operations per year, while only 120,000 are performed (Davidson, 2015). NH delivers world-class cardiac care and addresses a social need by helping the poor population. Although $\mathrm{NH}$ is a for-profit, cardiac-care, multispecialty hospital chain, this study argues that it displays elements of social innovation and frugal innovation. In other words, this case exhibits the social dimension of frugal innovation as NH fulfils basic needs, improves human well-being, promotes social inclusion, helps extend life expectancy and rebalances economic inequalities in society. Table 2 illustrates how a frugal innovation, $\mathrm{NH}$, fulfils social innovation characteristics. 
Table 2 Analysing NH through social innovation characteristics

\begin{tabular}{|c|c|c|c|c|c|}
\hline $\begin{array}{l}\text { Social } \\
\text { innovation } \\
\text { characteristics }\end{array}$ & $\begin{array}{l}\text { Sustainable } \\
\text { solution }\end{array}$ & $\begin{array}{l}\text { Novel solution } \\
\text { beneficial for } \\
\text { society }\end{array}$ & $\begin{array}{c}\text { Socially } \\
\text { inclusive and } \\
\text { rebalances } \\
\text { power } \\
\text { disparities }\end{array}$ & $\begin{array}{l}\text { Overcomes } \\
\text { societal } \\
\text { challenges }\end{array}$ & $\begin{array}{c}\text { Improves } \\
\text { human } \\
\text { capabilities } \\
\text { and promotes } \\
\text { well-being }\end{array}$ \\
\hline $\begin{array}{l}\text { Narayana } \\
\text { Hrudayalaya }\end{array}$ & $\begin{array}{l}\text { Implements } \\
\text { a highly } \\
\text { innovative } \\
\text { healthcare } \\
\text { model and offers } \\
\text { sustainable, } \\
\text { cardiac care at } \\
\text { low cost. }\end{array}$ & $\begin{array}{l}\text { Offers a } \\
\text { micro-insurance } \\
\text { scheme through } \\
\text { which the poor } \\
\text { can access } \\
\text { quality } \\
\text { healthcare. }\end{array}$ & $\begin{array}{l}\text { Offers free or } \\
\text { discounted } \\
\text { treatment to } \\
\text { marginalised } \\
\text { people. }\end{array}$ & $\begin{array}{l}\text { Provides } \\
\text { affordable } \\
\text { heart surgery } \\
\text { in a world } \\
\text { when only } \\
8 \% \text { of the } \\
\text { population } \\
\text { has access } \\
\text { to it. }\end{array}$ & $\begin{array}{l}\text { Offers } \\
\text { world-class } \\
\text { cardiac care } \\
\text { at a radically } \\
\text { low cost. }\end{array}$ \\
\hline
\end{tabular}

\subsection{GE's MAC 400 ECG machine}

\subsubsection{Case description}

GE's MAC 400 ECG machine is a portable electrocardiogram that costs one-tenth and weighs one-fifth of its current equivalent in western markets (Radjou et al., 2012). GE healthcare developed it in India in 2008, aiming to develop a portable ECG machine that could reach rural communities, as the existing devices were unfeasible to use in the emerging markets. The existing ECG machines were heavy and thus could not be carried to remote villages. Moreover, they were very expensive and unaffordable for physicians in emerging markets. GE healthcare developed MAC 400 in 18 months and with a budget of just US\$500,000 (Bound and Thornton, 2012). Its low price, US\$1,000, was achieved by using off-the-shelf components like, for instance, a rugged printer, an adapted version of the portable ticket machine used in Indian bus kiosks (Radjou et al., 2012).

\subsubsection{Analysis of GE's MAC 400 ECG machine from the social innovation perspective}

Social innovation is broadly defined as something that benefits people or our planet (Centre for Social Innovation, 2013) and new ideas that accomplish social goals (Mulgan et al., 2007). As seen, GE's MAC 400 ECG machine, which is a reliable, affordable, easy-to-use intensity innovation, achieves clear social impacts (Cernikovaite and Lauzikas, 2011) by enabling the treatment of poor patients living in far-flung remote villages, thereby promoting human well-being. GE healthcare's MAC 400 is not only a frugal innovation but it can also be seen as a social innovation that benefits people.

GE's MAC 400 is an innovation that was developed after recognising the problem of physicians in the emerging markets being unable to afford the existing technology and the lack of availability of the best-suited devices for these markets. It is a novel technology that fulfils social goals. In this context, this new idea that successfully materialised to accomplish social goals and solve societal challenges can be seen as a social innovation. Table 3 illustrates how a frugal innovation, GE's MAC 400 ECG machine, fulfils social innovation characteristics. 
Table 3 Analysing GE's MAC 400 through social innovation characteristics

\begin{tabular}{|c|c|c|c|c|c|}
\hline $\begin{array}{l}\text { Social } \\
\text { innovation } \\
\text { characteristics }\end{array}$ & $\begin{array}{l}\text { Sustainable } \\
\text { solution }\end{array}$ & $\begin{array}{l}\text { Novel solution } \\
\text { beneficial for } \\
\text { society }\end{array}$ & $\begin{array}{c}\text { Socially } \\
\text { inclusive and } \\
\text { rebalances } \\
\text { power } \\
\text { disparities }\end{array}$ & $\begin{array}{l}\text { Overcomes } \\
\text { societal } \\
\text { challenges }\end{array}$ & $\begin{array}{c}\text { Improves } \\
\text { human } \\
\text { capabilities and } \\
\text { promotes } \\
\text { well-being }\end{array}$ \\
\hline $\begin{array}{l}\text { General } \\
\text { electric's } \\
\text { MAC } 400 \\
\text { ECG machine }\end{array}$ & $\begin{array}{l}\text { Light-weight, } \\
\text { compact, } \\
\text { portable and } \\
\text { easy to use } \\
\text { solution } \\
\text { that has } \\
\text { substantially } \\
\text { reduced the } \\
\text { ECG costs. }\end{array}$ & $\begin{array}{l}\text { Directly } \\
\text { benefits poor } \\
\text { patients by } \\
\text { providing them } \\
\text { access to a } \\
\text { much-needed } \\
\text { innovative } \\
\text { technology. }\end{array}$ & $\begin{array}{l}\text { Designed } \\
\text { specifically } \\
\text { for patients } \\
\text { living in } \\
\text { remote } \\
\text { villages. }\end{array}$ & $\begin{array}{l}\text { Tackles the } \\
\text { challenge of } \\
\text { unaffordability } \\
\text { of expensive } \\
\text { technology. }\end{array}$ & $\begin{array}{l}\text { Enables the } \\
\text { treatment of } \\
\text { patients living } \\
\text { in remote } \\
\text { far-flung areas. }\end{array}$ \\
\hline
\end{tabular}

\subsection{Siemens CT scanner (SOMATOM Spirit)}

\subsubsection{Case description}

Siemens designed an entry-level computed tomography (CT) system scanner in China for healthcare professionals called SOMATOM Spirit. This device design uses industrial design thinking principles and takes into account simplicity and users' needs. SOMATOM Spirit is a simple device that can be operated by less-qualified healthcare workers, such as technicians. It outperforms previous models due to its speed and simplicity. It scans more patients daily and consumes less energy compared to the previous models, reducing treatment costs by $30 \%$ and radiation dosage by up to $60 \%$ (Radjou and Prabhu, 2015). Initially designed for Chinese users, SOMATOM Spirit has found its way to developed markets in the USA and Europe. It has proven to be quite a popular device, and even hospitals in developed markets are finding it beneficial, as they are required to deliver quality healthcare at a lower cost (Radjou and Prabhu, 2015).

\subsubsection{Analysis of the Siemens CT scanner (SOMATOM Spirit) from the social innovation perspective}

As a frugal innovation, SOMATOM Spirit is an improved solution, much more efficient than the existing solutions. Radjou and Prabhu (2015) view this device as a simple yet effective and sustainable technology as it consumes much less energy compared to the previous models, is much easier to use, saves treatment costs and significantly reduces radiation dosages. The social dimension of this frugal innovation is also visible in its innovation and design process based on principles of design thinking and participatory innovation that consider users' needs and participation. SOMATOM Spirit presents a case not only of frugal innovation but also of social innovation.

Although a commercial product, the Siemens CT scanner (SOMATOM Spirit) introduces commendable value for people. Therefore, this innovation provides gain not only for the company but also for the people. Beyond Chinese society, this product benefits other societies, providing the opportunity to use a simple, effective, cheaper and sustainable solution to effectively meet users' needs. Table 4 illustrates how this frugal innovation fulfils social innovation characteristics. 
Table 4 Analysing SOMATOM Spirit through social innovation characteristics

\begin{tabular}{|c|c|c|c|c|c|}
\hline $\begin{array}{l}\text { Social } \\
\text { innovation } \\
\text { characteristics }\end{array}$ & $\begin{array}{l}\text { Sustainable } \\
\text { solution }\end{array}$ & $\begin{array}{c}\text { Novel } \\
\text { solution } \\
\text { beneficial for } \\
\text { society }\end{array}$ & $\begin{array}{c}\text { Socially } \\
\text { inclusive and } \\
\text { rebalances } \\
\text { power } \\
\text { disparities }\end{array}$ & $\begin{array}{l}\text { Overcomes } \\
\text { societal } \\
\text { challenges }\end{array}$ & $\begin{array}{c}\text { Improves } \\
\text { human } \\
\text { capabilities } \\
\text { and } \\
\text { promotes } \\
\text { well-being }\end{array}$ \\
\hline $\begin{array}{l}\text { Siemens CT } \\
\text { scanner } \\
\text { (SOMATOM } \\
\text { Spirit) }\end{array}$ & $\begin{array}{l}\text { Consumes less } \\
\text { energy, reduces } \\
\text { treatment costs } \\
\text { by } 30 \% \text { and } \\
\text { radiation } \\
\text { dosage by } \\
\text { up to } 60 \% \text {. }\end{array}$ & $\begin{array}{l}\text { Provides } \\
\text { a simple, } \\
\text { effective and } \\
\text { affordable } \\
\text { solution to } \\
\text { many } \\
\text { patients. }\end{array}$ & $\begin{array}{l}\text { Designed to be } \\
\text { operated by } \\
\text { less-qualified } \\
\text { healthcare } \\
\text { workers, such as } \\
\text { technicians. }\end{array}$ & $\begin{array}{l}\text { Tackles the } \\
\text { challenge of } \\
\text { unaffordability } \\
\text { of expensive } \\
\text { technology. }\end{array}$ & $\begin{array}{l}\text { Enables } \\
\text { affordable } \\
\text { treatment } \\
\text { of poor } \\
\text { patients. }\end{array}$ \\
\hline
\end{tabular}

\subsection{Vortex's solar powered ATM}

\subsubsection{Case description}

Vortex Engineering's solar-powered automated teller machines (ATMs) are efficient, environmentally friendly and easy to use (Vortex Engineering Private Limited, 2013). These ATMs are specifically designed to meet the requirements of rural and semi-urban areas that have unreliable power supplies and higher illiteracy levels of end-users (Tiwari and Herstatt, 2012a; Khan, 2016). Vortex Engineering designed and built an ATM with a solar panel that consumes approximately $10 \%$ of total energy required by a conventional ATM (Vortex Engineering Private Limited, 2013). It generates less heat and thus reduces the need for continuous air conditioning (Bound and Thornton, 2012). Further, it operates with temperatures ranging between $0^{\circ} \mathrm{C}$ and $50^{\circ} \mathrm{C}$ (Vortex Engineering Private Limited, 2013). Vortex ATMs are suitable for uneducated rural people, as they possess a built-in fingerprint identification system that eliminates the need for a personal identification number (Tiwari and Herstatt, 2012a). The Vortex machines are half the price of conventional ATMs (Vortex Engineering Private Limited, 2013).

\subsubsection{Analysis of Vortex's solar powered ATM from the social innovation perspective}

Vortex's solar powered ATM is a good example of both social as well as frugal innovation. Vortex's ATMs were designed for the semi-urban and rural India using the principles of frugal engineering. With about $80 \%$ of India's population in rural areas and fewer than 10,000 ATMs, there was a huge need for installing ATMs in rural India (Shivapriya, 2010). Vortex has widened financial inclusion across rural India by serving mostly underserved customers (Bound and Thornton, 2012). Vortex's ATMs incorporate many innovative techniques that enable them to offer a low-cost, rugged and reliable, low-power product that suits the rural and semi-urban areas.

Vortex's solar powered ATM, a novel solution, provides poor rural customers access to banking services, who are otherwise devoid of such services mainly due to viability reasons. People living in rural India have to travel miles for basic amenities such as food and medical facilities (Shivapriya, 2010). In such circumstances, access to banking 
services has become possible only because of this remarkable innovation. Table 5 illustrates how this frugal innovation fulfils social innovation characteristics.

Table 5 Analysing Vortex's solar powered ATM through social innovation characteristics

\begin{tabular}{|c|c|c|c|c|c|}
\hline $\begin{array}{l}\text { Social } \\
\text { innovation } \\
\text { characteristics }\end{array}$ & $\begin{array}{c}\text { Sustainable } \\
\text { solution }\end{array}$ & $\begin{array}{l}\text { Novel solution } \\
\text { beneficial for } \\
\text { society }\end{array}$ & $\begin{array}{l}\text { Socially } \\
\text { inclusive and } \\
\text { rebalances } \\
\text { power } \\
\text { disparities }\end{array}$ & $\begin{array}{l}\text { Overcomes } \\
\text { societal } \\
\text { challenges }\end{array}$ & $\begin{array}{c}\text { Improves } \\
\text { human } \\
\text { capabilities } \\
\text { and promotes } \\
\text { well-being }\end{array}$ \\
\hline $\begin{array}{l}\text { Vortex } \\
\text { Engineering } \\
\text { (Solar powered } \\
\text { ATM) }\end{array}$ & $\begin{array}{l}\text { Solar-powered, } \\
\text { and consumes } \\
\text { almost } 10 \% \text { of } \\
\text { the total energy } \\
\text { required by a } \\
\text { regular ATM. }\end{array}$ & $\begin{array}{l}\text { Benefits } \\
\text { uneducated } \\
\text { rural masses } \\
\text { by widening } \\
\text { financial } \\
\text { inclusion. }\end{array}$ & $\begin{array}{l}\text { Illiterate } \\
\text { people are } \\
\text { able to access } \\
\text { ATMs using } \\
\text { a fingerprint } \\
\text { identification } \\
\text { system. }\end{array}$ & $\begin{array}{l}\text { Tackles the } \\
\text { challenge of } \\
\text { financial } \\
\text { exclusion } \\
\text { across rural } \\
\text { areas. }\end{array}$ & $\begin{array}{l}\text { Empowers } \\
\text { rural people } \\
\text { by granting } \\
\text { them access } \\
\text { to banking } \\
\text { services. }\end{array}$ \\
\hline
\end{tabular}

Table 6 Summary of the cases as frugal and social innovations

Socially driven

Narayana

Hrudayalaya innovation

$$
\text { Why a frugal innovation? }
$$

- Provides affordable, quality healthcare.

- Delivers high-quality and cost-effective healthcare by applying the principles of mass production.

- Reduces heart surgery costs significantly, ranging from US $\$ 2,000$ to $\$ 5,000$.

General electric's MAC 400 ECG machine
- MAC 400 costs one-tenth and weighs one-fifth of its equivalent in western markets.

- Reduces the cost of an ECG to just US\$1 per patient.

- Lightweight, compact, portable, battery-powered and easy to operate.

\section{Why a social innovation?}

- Promotes well-being by offering healthcare at radically low costs, thus extending life expectancy.

- Offers a micro-insurance scheme through which people with low means access quality healthcare at five Indian rupees per month.

- Performs at least 60 operations for low-income patients free of charge weekly, thus contributing to rebalancing economic inequalities in society.

- The battery-powered ECG machines are easier to carry on bikes while visiting patients in rural areas, thus enabling the treatment of poor patients living in these remote areas.

- Achieves social impact by promoting human well-being. 
Table 6 Summary of the cases as frugal and social innovations (continued)

\begin{tabular}{|c|c|c|}
\hline $\begin{array}{l}\text { Socially driven } \\
\text { innovation }\end{array}$ & Why a frugal innovation? & Why a social innovation? \\
\hline $\begin{array}{l}\text { Siemens CT Scanner } \\
\text { (SOMATOM Spirit) }\end{array}$ & $\begin{array}{l}\text { - Is affordable and cheaper than } \\
\text { the alternatives. } \\
\text { - Is simple enough to be operated } \\
\text { by less-qualified healthcare } \\
\text { workers, such as technicians. } \\
\text { - Scans more patients daily and } \\
\text { consumes less energy, reducing } \\
\text { treatment costs by } 30 \% \text { and } \\
\text { radiation dosage by up to } 60 \% \text {. }\end{array}$ & $\begin{array}{l}\text { - Provides a simple, effective, } \\
\text { cheap, sustainable solution to } \\
\text { many users globally. } \\
\text { - Based on product design and } \\
\text { participatory innovation, taking } \\
\text { into account users' needs and } \\
\text { participation. } \\
\text { - Improves the macro-level } \\
\text { quality of life. }\end{array}$ \\
\hline $\begin{array}{l}\text { Vortex's solar } \\
\text { powered ATM }\end{array}$ & $\begin{array}{l}\text { - Vortex machines are half the } \\
\text { price of conventional ATMs. } \\
\text { - Very low operating expenses - } \\
\text { low power consumption and } \\
\text { communication costs. } \\
\text { - Rugged, reliable, easy to use } \\
\text { and environmentally friendly. }\end{array}$ & $\begin{array}{l}\text { - Widens financial inclusion } \\
\text { across rural India. } \\
\text { - Empowers rural population of } \\
\text { India by providing them access } \\
\text { to banking services. } \\
\text { - Using a fingerprint } \\
\text { identification system, illiterate } \\
\text { people are given an opportunity } \\
\text { to use ATMs. }\end{array}$ \\
\hline
\end{tabular}

\subsection{Summary of the cases}

Table 6 summarises the cases and their characteristics as both frugal and social innovations, partly distinct, and partly intertwined.

\section{Discussion}

So far, social innovation and frugal innovation have been studied as different concepts. Social innovation has focussed on bringing value to society as a whole rather than to specific individuals (Phills et al., 2008) and frugal innovation has mostly been associated with MNCs or other businesses and their ability to employ frugal techniques in order to stay competitive in the market (Zeschky et al., 2011). However, they have similarities, and this paper studies social innovation and frugal innovation in relation to one another. According to the EU (2012), social innovation should address a social demand and contribute to reshaping society through participation, empowerment and learning. Thus, social innovation either emerges in response to the need for a system change (in the context of societal challenges) or is driven by social values (e.g., participation, democracy, citizen empowerment and social cohesion). Aligning with the discussion on frugal innovation, many innovations emerge under frugal conditions to address specific societal problems. Usually, such affordable solutions have an obvious social ambition as they address the persistent, fundamental needs of local masses that would otherwise remain unfulfilled [EU - European Commission, (2016), p.11]. 
This study reveals the blurred boundaries between frugal innovation and social innovation as both solve pressing, unaddressed societal needs and add value to society. The authors, therefore, see them as related sister concepts not previously studied in relation to each other. Frugal innovation and social innovation are both socially driven innovations that generate social value. Socially driven innovation thus incorporates social innovation and frugal innovation under one umbrella term.

Frugal innovation creates more business and social value by minimising resource use (Radjou and Prabhu, 2014). It adds value by producing simple solutions cheaper than the alternatives, and when the costs of products and services are lowered significantly, those on the margins of society often are included in the mainstream, allowing non-consumers to be consumers - itself a social innovation.

For example, NH's micro-insurance scheme provides millions access to affordable healthcare. GE's MAC 400 ECG machine solves the challenge of treating patients in rural areas that lack proper infrastructure. The Siemens CT scanner (SOMATOM Spirit) provides millions with a simpler, more effective, cheaper, more sustainable tool than existing solutions. Vortex's ATM provides the poorest in society access to ATMs, who are otherwise excluded from banking services. In all these examples, it is evident that these frugal innovations fulfil social demands not addressed by traditional institutions and are targeted at underprivileged masses. Empowerment of those on the margins of society improves well-being and quality of life, alleviates poverty and increases access to services to meet basic needs. As explained, these traits are the qualities of social innovation and, in this case, are fulfilled by frugal innovation. In these examples, the authors, therefore, see blurred lines between frugal and social innovation. All the definitions of social innovation discussed - "social innovation is a novel solution to a social problem with great societal value" (BEPA, 2010); "it improves 'macro' quality of life - quality of life in relation to a group of individuals and/or quantity of life" (Pol and Ville, 2009); "it benefits people or planet earth" (Centre for Social Innovation, 2013) and "it is more efficient, effective or sustainable than the existing solutions" (Phills et al., 2008) - are aptly applied to the four selected examples of frugal innovation, as shown in the previous section. Moreover, all the cases of frugal innovation fulfil the five characteristics of social innovation derived from the social innovation literature.

Furthermore, the process of social innovation is not linear. The end-use of an innovation may be very different from what was initially visualised; sometimes, action precedes understanding, and sometimes, taking action crystallises an idea. Real innovations are not straight lines; instead, they are spirals (BEPA, 2010). The innovations described in this paper also ultimately acquire characteristics and impacts not originally envisaged. Socially driven innovations imply nonlinear social learning processes that unfold over time. Exclusively socially driven innovations are embedded in their material contexts. Socially driven innovation in services, for instance, are much more complex than earlier technology adoption perspectives propose. Social and technological (frugal) innovations can be seen as intertwined and interactive.

Accordingly, it is implied that frugal innovation has a strong social dimension and is linked to social innovation as both are socially driven innovations (see also Khan, 2017), increasing empowerment and improving well-being. Figure 1 illustrates socially driven innovation as an umbrella concept encompassing frugal innovation and social innovation and represents the blurred lines between them. 
Figure 1 Blurred boundaries between frugal innovation and social innovation (see online version for colours)

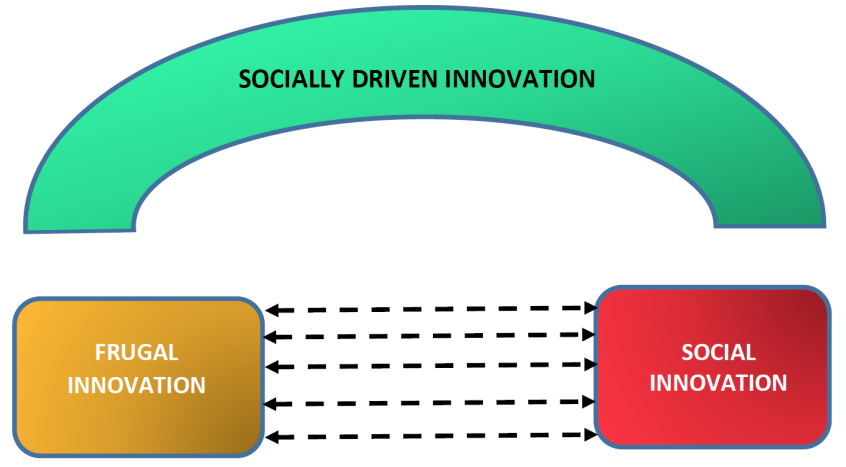

\section{Conclusions}

\subsection{Theoretical and managerial implications}

This study contributes to the frugal innovation literature by considering the similarities between frugal innovation and social innovation in a novel way. The authors discuss the blurred boundaries between frugal and social innovation, both solving pressing societal needs and bringing value to society. In some cases, it becomes hard to distinguish between them. This study presents a novel view of frugal innovation and social innovation as sister concepts, which can be studied in relation to one another under the umbrella concept of socially driven innovation, defined as solutions and processes that result in empowerment and well-being.

Frugal innovators can use the knowledge from this research to benefit their organisations. They can market frugal products and services by highlighting their social impact in a more focussed, pronounced manner. Organisations already involved in innovating frugally and producing efficient frugal products and services can identify the social value they generate and recognise the characteristics of social innovations, which can assist in effectively promoting their products and services.

\subsection{Limitations and further research}

This paper has its limitations. While selecting four cases for the purpose of this study, the authors could have chosen many other cases representing only one country to provide a more detailed illustration of the connection. However, this study chose to include frugal innovations from other countries to show the impact of frugal innovation on different societies rather than only one country. Furthermore, frugal innovation is a relatively new research field, and its social dimension is the least researched topic. To study this dimension, the authors, therefore, demonstrate the link between frugal innovation and social innovation by exploring the definitions of social innovation. However, the authors do not claim that this is the only possible way to evaluate this relationship.

Regarding future research, this little-researched field offers further opportunities to explore this topic as this study has initiated the discussion on the social dimension of 
frugal innovations with a few selected cases. It is recommended to pursue a follow-up study that can demonstrate a stronger relationship between frugal and social innovations. Researchers can investigate different frugal innovation case studies to better understand and improve knowledge of the social dimension of frugal innovation. It will also be beneficial to study the social processes of frugal innovation to answer unaddressed questions concerning its societal significance.

\subsection{Conclusions}

Many important areas of frugal innovation research are still in their infancy, and studies on its social dimension remain scarce. It is crucial to demonstrate the importance of the social value that frugal innovation brings to society in order to understand its inherent nature. Such knowledge may also help frugal innovators overcome various prejudices (e.g., frugal solutions have poor quality and are applicable only in emerging markets). With this aim in mind, this study explores the social dimension of frugal innovation by showing its potential to act as social innovations in many contexts. The authors examine cross-industry and cross-national examples of successful frugal innovation from the perspective of social innovation and trace the blurred boundaries between frugal innovation and social innovation that, in some cases, make it difficult to determine the differences between the two. This study proposes socially driven innovation as an umbrella concept incorporating frugal innovation and social innovation.

\section{Acknowledgements}

This work was supported by Business Finland (formerly Tekes; the project: 'Scalable mobile learning services for emerging markets', SCALA).

\section{References}

Angot, J. and Ple, L. (2015) 'Serving poor people in rich countries: the bottom-of-the-pyramid business model solution', Journal of Business Strategy, Vol. 36, No. 2, pp.3-15.

Ayob, N., Teasdale, S. and Fagan, K. (2016) 'How social innovation 'came to be': tracing the evolution of a contested concept', Journal of Social Policy, Vol. 45, No. 4, pp.635-653, DOI: $10.1017 / \mathrm{S} 004727941600009 X$.

Basu, R.R., Banerjee, P.M. and Sweeny, E.G. (2013) 'Frugal innovation: core competencies to address global sustainability', The Journal of Management for Global Sustainability, Vol. 1, No. 2, pp.63-82.

BEPA (2010) Study on Social Innovation, Brussels, Bureau of European Policy Advisors/ European Union/The Young Foundation.

Bessant, J. (2016) Frugal Innovation, Innovation Portal [online] http://www.innovationportal.info/frugal-innovation/\#_ftn6 (accessed 15 November 2017).

Bhatti, Y.A. (2012) What is Frugal, What is Innovation? Towards a Theory of Frugal Innovation [online] http://ssrn.com/abstract=2005910 (accessed 14 November 2017).

Bound, K. and Thornton, I.W. (2012) Our Frugal Future: Lessons from India's Innovation System, Nesta, London, UK.

Centre for Social Innovation (2013) [online] http://socialinnovation.ca/about/social-innovation (accessed 24 November 2017). 
Cernikovaite, M. and Lauzikas, M. (2011) 'The model of social innovations in the emerging market of Lithuania', Intellectual Economics, Vol. 3, No. 11, pp.388-400.

Chiappero-Martinetti, E., Houghton Budd, C. and Ziegler, R. (2017) 'Social innovation and the capability approach - introduction to the special issue', Journal of Human Development and Capabilities, Vol. 18, No. 2, pp.141-147, DOI: 10.1080/19452829.2017.1316002.

Davidson, L. (2015) Do Frugal Innovations Lead to Frugal Outcomes? A Case Study of Healthcare in India, Wharton Research Scholars, p.127 [online] http://repository.upenn.edu/ wharton_research_scholars/127 (accessed 24 November 2017).

EU - European Commission (2016) A Conceptual Analysis of Foundations, Trends and Relevant Potentials in the Field of Frugal Innovation (for Europe), Interim Report, Prepared for the European Commission Directorate General for Research and Innovation.

EU (2012) Work Programme 2013, Cooperation, Theme 8, Socio-Economic Sciences and Humanities, European Commission C, 4536, European Commission, 9 July.

Fressoli, M., Arond, E., Abrol, D., Smith, A., Ely, A. and Dias, R. (2014) 'When grassroots innovation movements encounter mainstream institutions: implications for models of inclusive innovation', Innovation and Development, Vol. 4, No. 2, pp.277-292.

Govindarajan, V. and Ramamurti, R. (2011) 'Reverse innovation, emerging markets, and global Strategy', Global Strategy Journal, Vol. 1, Nos. 3-4, pp.191-205.

Hämäläinen, H. (2005) 'Innovaatiotoiminnalla ratkaisuja hyvinvointiyhteiskunnan tulevaisuuden haasteisiin (Innovation activities as a solution to future challenges of the welfare society)', Yhteiskuntapolitiikka, in Finnish, Vol. 70, No. 2, pp.197-204.

Hart, S.L. and Christensen, C.M. (2002) 'The great leap. Driving innovation from the base of the pyramid', MIT Sloan Management Review, Vol. 44, No. 1, pp.51-56.

Hautamäki, A. (2007) Kestävä innovointi. Innovaatiopolitiikka uusien haasteiden edessä (Sustainable Innovation. Innovation Policy in Front of New Challenges), in Finnish, Series, Sitran raportteja 76, Sitra, Helsinki.

Heiskala, R. (2007) 'Social innovations: structural and power perspectives', in Hämäläinen, T. and Heiskala, R. (Eds.): Social Innovations, Institutional Change and Economic Performance. Making Sense of Structural Adjustment Processes in Industrial Sectors, Regions and Societies, pp.52-79, Edward Elgar Publishers, Cheltenham.

Hennala, L. (2011) Kuulla vai kuunnella - käyttäjää osallistavan palveluinnovoinnin lähestymistavan toteuttamisen haasteita julkisella sektorilla (To Hear or to Listen Challenges of Implementing the User Involvement Approach in Service Innovation in the Public Sector), in Finnish, Lappeenranta University of Technology, Lappeenranta.

Hennala, L., Konsti-Laakso, S. and Harmaakorpi, V. (2012) 'Challenges of bringing citizen knowledge into public sector service innovation', in Melkas, H. and Harmaakorpi, V. (Eds.): Practice-Based Innovation: Insights, Applications and Policy Implications, pp.255-275, Springer, Berlin/Heidelberg.

Hennala, L., Parjanen, S. and Uotila, T. (2011) 'Challenges of multi-actor involvement in the public sector front-end innovation processes - constructing an open innovation model for developing well-being services', European Journal of Innovation Management, Vol. 14, No. 3, pp.364-387.

Joutsenoja, M. and Lindh, J. (2004) 'Sosiaaliset innovaatiot: mobilisaatioharjoitus (Social innovations: a mobilization exercise)', in Lemola, T. and Honkanen, P. (Eds.): Innovaatiopolitiikka - Kenen hyväksi, keiden ehdoilla?, in Finnish, pp.49-61, Gaudeamus, Helsinki.

Khan, R. (2016) 'How frugal innovation promotes social sustainability', Sustainability, Vol. 8, No. 1034.

Khan, R. (2017) The Contribution of Socially Driven Businesses and Innovations to Social Sustainability, Acta Universitatis Lappeenrantaensis 743, Yliopistopaino, Lappeenrannan Teknillinen Yliopisto. 
Moulaert, S., Maccallum, D., Mehmood, A. and Hamdouch, A. (2013) The International Handbook on Social Innovation: Collective Action, Social Learning and Transdisciplinary Research, Elgar Original Reference, Edward Elgar, Cheltenham.

Mulgan, G., Tucker, S., Ali, R. and Sanders, B. (2007) 'Social Innovation: what it is, why it matters, how it can be accelerated', Young Foundation [online] http://www.youngfoundation. org/files/images/03_07_What_it_is_SAID_pdf (accessed 20 November 2017).

Nicholls, A. and Ziegler, R. (2015) An Extended Social Grid Model for the Study of Marginalization Processes and Social Innovation, CRESSI Working Papers No. 2, University of Oxford [online] https://www.sbs.ox.ac.uk/sites/default/files/research-projects/CRESSI/ docs/CRESSI_Working_Paper_2_D1.1_Chp2_18Nov2014.pdf (accessed 21 November 2017).

Onwuegbuzie, A.J. and Leech, N.L. (2007) 'Sampling designs in qualitative research: making the sampling process more public', The Qualitative Report, Vol. 12, No. 2, pp.238-254 [online] http://nsuworks.nova.edu/tqr/vol12/iss2/7 (accessed 24 November 2017).

Osborne, S.P. and Brown, L. (2011) 'Innovation, public policy and public services delivery in the UK. The word that would be king?', Public Administration, DOI: 10.1111/j.1467-9299. 2011.01932.x.

Pansera, M. and Sarkar, S. (2016) 'Crafting sustainable development solutions: frugal innovations of grassroots entrepreneurs', Sustainability, Vol. 8, No. 1, p.51.

Papaioannou, T. (2014) 'How inclusive can innovation and development be in the twenty-first century?', Innovation and Development, Vol. 4, No. 2, pp.187-202.

Phills Jr., J.A., Deiglmeier, K. and Miller, D.T. (2008) Rediscovering Social Innovation, Stanford Centre for Social Innovation Review [online] http://www.ssireview.org/articles/entry/ rediscovering_social_innovation (accessed 14 November 2017).

Pisoni, A., Michelini, L. and Martignoni, G. (2018) 'Frugal approach to innovation: state of the art and future perspectives', Journal of Cleaner Production, Supplement C, Vol. 171, pp.107-126.

Pol, E. and Ville, S. (2009) 'Social innovation: buzz word or enduring term', The Journal of Socio-Economics, Vol. 38, No. 6, pp.878-885.

Prahalad, C.K. (2010) The Fortune at the Bottom of the Pyramid: Eradicating Poverty through Profits, 2nd ed., Pearson Education, Upper Saddle River, NJ, USA.

Prahalad, C.K. and Hart, S.L. (2002) The Fortune at the Bottom of the Pyramid, Strategy + Business [online] http://www.cs.berkeley.edu/ brewer/ict4b/Fortune-BoP.pdf (accessed 27 November 2017).

Putnam, H. (2002) The Collapse of the Fact/Value Dichotomy and Other Essays, Harvard University Press, Cambridge, MA.

Radjou, N. and Prabhu, J. (2014) Frugal Innovation: How to Do More with Less, 1st ed., Profile Books Ltd., London, UK.

Radjou, N. and Prabhu, J. (2015) The Frugal Way to Grow, Frugal Innovation Hub [online] https://frugalinnovationhub.com/en/resources/2015/11/02/the-frugal-way-to-grow.html (accessed 26 November 2017).

Radjou, N., Prabhu, J. and Ahuja, S. (2012) Jugaad Innovation: Think Frugal, Be Flexible, Generate Breakthrough Growth, Jossey-Bass, San Francisco, CA, USA.

Rao, B.C. (2013) 'How disruptive is frugal?', Technology in Society, Vol. 35, No. 1, pp.65-73.

Shivapriya, N. (2010) 'Vortex engineering's Gramateller ATM for rural India', The Economic Times [online] http//economictimes.indiatimes.com/articleshow/6503231.cms?utm_source= contentofinterest\&utm_medium=text\&utm_campaign=cppst (accessed 30 December 2017$)$.

Smith, A., Fressoli, M. and Thomas, H. (2014) 'Grassroots innovation movements: challenges and contributions', Journal of Cleaner Production, Vol. 63, No. 3, pp.114-124.

Soni, P. and Krishnan, R.T. (2014) 'Frugal innovation: aligning theory, practice, and public policy', Journal of Indian Business Research, Vol. 6, No. 1, pp.29-47. 
Ståhle, P., Sotarauta, M. and Pöyhönen, A. (2004) Innovatiivisten ympäristöjen ja organisaatioiden johtaminen (Management of Innovative Environments and Organizations), in Finnish, Tulevaisuusvaliokunta, Teknologian arviointeja 19, Series: Eduskunnan kanslian julkaisu, Eduskunta, Helsinki.

Tiwari, M. (2017) 'Exploring the role of the capability approach in social innovation', Journal of Human Development and Capabilities, Vol. 18, No. 2, DOI: 10.1080/19452829. 2016.1271312.

Tiwari, R. and Herstatt, C. (2012a) 'Frugal innovation: a global networks' perspective', Die Unternehmung, Vol. 66, No. 4, pp.245-274.

Tiwari, R. and Herstatt, C. (2012b) India - a Lead Market for Frugal Innovations? Extending the Lead Market Theory to Emerging Economies, Working Paper No. 67, Institute for Technology and Innovation Management, Hamburg University of Technology, Hamburg, Germany.

Van de Ven, A. (1988) 'Central problems in the management of innovation', in Tushman, M. and Moore, W. (Eds.): Readings in the Management of Innovation, pp.103-22, Ballinger, Cambridge, MA.

Vortex Engineering Private Limited (2013) [online] http://vortexindia.co.in/ (accessed 30 May 2018).

Weyrauch, T. and Herstatt, C. (2017) 'What is frugal innovation? Three defining criteria', Journal of Frugal Innovation, Vol. 2, No. 1, pp.1-17.

Yin, R.K. (2009) Case Study Research: Design and Methods, 4th ed., Sage, Los Angeles, CA.

Zeschky, M., Widenmayer, B. and Gassmann, O. (2011) 'Frugal innovation in emerging markets: the case of Mettler Toledo', Research Technology Management, Vol. 54, pp.38-45.

Zeschky, M.B., Winterhalter, S. and Gassmann, O. (2014) 'From cost to frugal and reverse innovation: mapping the field and implications for global competitiveness', Research Technology Management, Vol. 57, No. 4, pp.20-27.

Ziegler, R. (2015) 'Social innovation as a collaborative concept', International Social Innovation Research Conference 2015, New York. 